\title{
THE INCREASED COST OF PRODUCTION
}

\author{
By Everett P. Whemler,
}

Chairman, Law Committee National Civil Service League, New York; Chairman, Committee American Bar Association on Remedies for Law's Delay.

Many causes for the increased cost of living have been assigned. No doubt many have combined to produce the result which we are considering today. Perhaps sufficient attention has not been paid to one of these, that is, the increased cost of production.

I had the good fortune once to examine Mr. Thomas A. Edison as an expert in a case relating to the ownership of his quadruplex patents. In the course of his testimony he uttered this profound truth: "The simplest things are always the best and the last to be found out."

As I have studied the increase in the cost of living it seems to me that this statement of Mr. Edison's is most applicable. The simple explanation of the increased cost of living is that the cost of production has increased. Let me call your attention to two subjects in which this is particularly true: the increase in house rent and in the price of meat.

First, in the matter of rent, let us deal especially with the rent of apartments in tenements in the cities. In 1860, a workingman could get as comfortable rooms in New York City for $\$ 8$ a month as he now can for \$16. The reason for this is mainly that the cost of building has greatly increased. This increase in the cost of building is due to two causes:

The increased governmental requirements in reference to the character of the buildings. Take for example the tenement house act of the state of New York which became a law April 12, 1901. The second chapter of this relates to protection from fire. Every tenement house is required to have a fireproof fire escape. In the construction of five story tenement houses the first floor above the cellar must be constructed fireproof with iron or steel beams and fireproof flooring. Many other requirements provide for the safety of the occupants 
which time forbids me to state in detail. All these reforms are enforced by govermental supervision. They all cost money, and the landlord must get a percentage of this cost out of the rent. The third chapter relates to light and ventilation. The first section of this is as follows: "No tenement house hereafter erected shall occupy more than 90 per cent of any corner, or more than 70 per cent of any other lot. The height shall not exceed by more than one-half the width of the widest street upon which it stands." The light and ventilation of the rooms are minutely regulated and the amount of space to be allotted to each apartment is determined. Compliance with these requirements of law cost money and this inevitably comes out of and increases rent. The fourth chapter contains many sanitary provisions. Every tenement house must have in each apartment running water. Water closets are required. Very strict requirements are made in regard to repairs.

Now I do not at all assert that any of these requirements are unwise. What I do say is that they involve expense and that the interest on this expense necessarily increases the rent of the property.

Another cause of the increase in rent is the great increase in taxation in cities. This is caused by increased public requirements. The amount of water used per capita has greatly increased. The streets are better paved, better lighted and better drained than they were fifty years ago. All these expenses are paid for by direct taxation upon the land. Practically the entire cost of administration in the cities of the United States is paid for by land tax. It is true that we are beginning to derive considerable revenue for our cities from public service corporations who exercise their franchises within the city limits. Also experience shows that the city piers and docks can be so managed as to yield a revenue which will pay the interest upon their cost and provide a sinking fund to pay the debt incurred in their construction. But nevertheless, it does remain true that up to the present time much the larger part of the city expenditure is paid for by direct land tax. This necessarily adds to the cost of property and necessarily increases the rental of it.

There is a third cause of the increase of rent which is perhaps even more effective than the two causes which I have mentioned already. That is the tariff. I have often been asked how it is that the tariff increases rent. My answer has always been, and no one has ever been able to challenge the correctness of the answer-it increases the rent 
by increasing the cost of construction of the buildings for which the rent is paid.

Some years ago I had occasion to build four tenement houses in New York City. I found that there was a tariff tax upon all the materials that entered into the construction of the houses. Stone, brick, lime, plaster, the lead pipe and the brass work of the plumbing, the hardware of the windows and the doors, the tin plate with which the roof was covered. In short not one item that went into those houses was on the free list. I made a computation of the effect of this tariff tax upon the cost and found that I could have built five houses for the same money if it had not been for the tariff tax upon the materials which composed them. I am willing to admit that when I built those houses I had some consideration for the comfort and convenience of the people that were to live in them. In short, I aimed to make them according to my light at the time, model tenement houses. This I am well aware is not commercial and I only mention it to guard against the charge that a landlord is necessarily entirely commercial in his plans and operations. But at the same time I did build them for an investment and in fixing the rents I sought to obtain a reasonable and legitimate rental. Had I been able to build five houses instead of four, I should not have charged any more rent for the five than I was obliged to for the four. In other words, the rent of each apartment, if I had built the five houses, would have been one-fifth less.

Again, in stating this as the cause, I am not arguing whether a high tariff is or is not wise legislation. All I at present maintain is that it does tend to increase the cost of house building because it increases the cost of the materials of which the house is made, and therefore compels the owner to ask a higher rent if he is to get a return for his investment.

And now I come to the increased cost of meat. Here we have the relation of cause and effect quite as marked.

In the year 1885, the conditions of the cattle industry in the United States were these: There were great tracts of government land in Nebraska, Wyoming and other states west of the Mississippi which were used as ranches. The ranchmen paid the government nothing for the use of these wild lands. They were open to the public and were used by the ranchmen for the raising of cattle both for beef and mutton. In order to prevent the cattle of one ranch straying to 
another, it was necessary to do some fencing, but otherwise the cost of production for beef and mutton from these ranches was a minimum. Thereupon some well meaning people raised loud outcry against what they called the cattle barons. The owners of these ranches were undoubtedly'making money and that was a grievance to many well meaning people. Even those reformers who keep the eighth commandment--."Thou shalt not steal" may be violators of the tenth commandment-" Thou shalt not covet." It is very certain that envious eyes during the year 1885 and prior thereto, were fixed upon the fortunes which were being made by the proprietors of these ranches. Undoubtedly also there were many persons who were free from this particular sin who yet thought it desirable that all these wild lands should be divided up in small plots, and sold to settlers. But they did not consider that necessarily such a change in the occupation of the land would increase the cost of producing beef and mutton which most people think are essential to health and comfort. Accordingly in the year 1885 Congress, upon the urgency of the reformers, passed an act prohibiting the enclosure of any public lands. It gave to the United States government the right to bring action to enjoin persons from maintaining such enclosures and to ask for an order of the court that they should be removed. The fifth section, which seems to have been an afterthought, is much more stringent and seems to dispense entirely with the second section. This authorizes the President to remove these fences by military force. Now our President in the year 1885 was Grover Cleveland. He was a person who believed in enforcing the laws and when this act of Congress was passed, he did enforce it. The result was that some of the large ranchmen who had made money for themselves and benefited the public by raising cattle on these wild lands of the west were driven out of business.

After a time the enforcing of this particular law was somewhat neglected. The business of ranching developed, but still many difficulties were thrown in their way and one difficulty, which possibly the framers of the act did not foresee was this: You are all aware that the government surveys lay out lands in squares, sections and quarter sections, like the squares of a checker board. Land grants of alternate sections had been made to the great lines of railroads running east and west. The sections not granted remained in the ownership of the government. The government officials after a while were advised 
that it was not lawful for the owner of one of the sections which had been granted to the railroads, and which had been leased by them to cattle men, to fence up his section, because that would interfere with the access to the government section. Obviously it would. If you will imagine a checker board, and undertake to put fences around every alternate section, you will at once perceive that they will be an obstruction to all the other squares. In short, as long as a man owns land adjoining a neighbor's land, whatever fence he puts at the border of his own land will be a line fence to his neighbor.

Then the lawyers, who are often charged with endeavors to evade the law, were called in by some of the ranchmen and asked if the law would prevent their leasing contiguous government lands and fencing the whole parcel. The lawyers advised that every citizen had the right to lease land belonging to another and that if it was right to lease one tract it was right to lease one hundred. Accordingly some of the ranchmen who were in the business of raising cattle and selling beef to the Chicago market, undertook the crime of leasing numerous sections of land which they had induced numerous individuals to take up under the homestead acts. They were indicted for a conspiracy to defraud the government. In this case it turned out that the courts did not agree with the lawyers. The federal court held that inasmuch as a combination was proved to lease numerous tracts of land and bring them all into one ranch and as the evident policy of the law was to compel the use of the lands in small parcels by individual settlers, this action of the ranchmen was a fraud upon the government, and they were convicted and sent to prison. One of them, who was one of the most prominent and most successful of all the cattle raisers in the west, died there.

Now it does not need any argument from me to show that this course of legislation and administration by the United States government from the year 1885 to the present time has operated to increase the cost of production of beef and mutton in the United States and to increase the price to the consumer. One would think in view of this well defined policy of the United States government that the consumers should have had influence enough, since the government was opposing the raising of beef and cattle on a large scale in the United States, to put beef and mutton on the free list so that we could import them freely as England does from the countries that have not such policy. In Australia and the Argentine the cattle are allowed to roam on the great plains and live upon the herbage that grows there. The 
cost of producing beef there is reduced to a minimum. But it has long been the policy of the United States government, in order to increase the cost of beef and mutton to consumers, to lay a tax upon beef and mutton imported from the Argentine and Australia.

Now again, I am not criticising the legislation. Each class of enactments had a distinct and definite purpose. What I do criticise is the folly and shortsightedness of the American people in not perceiving that the inevitable effect of this legislation would be to increase the cost to the consumer.

Some statistics on this subject may interest you: The value of cattle on farms in the United States on January, 1907, was $\$ 72,500,000$; in January, 1912 , it was only $\$ 58,000,000$. Between 1900 and 1912 the supply of beef cattle was reduced 28 per cent; the population increased 25 per cent. In 1904 we exported 593,000 head of cattle, valued at. $\$ 42,000,000$; in 1911 we exported 150,000 head of cattle, valued at $\$ 13,000,000$. In 1901 we exported $351,000,000$ pounds of fresh beef and in 1911 we exported only $42,000,000$ pounds of fresh beef. You see how effective our restrictive laws have been. ${ }^{1}$

There is another change in legislation and in public sentiment which has greatly increased the cost of production to which I finally call your attention. I am now one of the veterans. In the days of my youth one of the prominent topics on the platform, in the press, and in the public schools was the dignity of labor. This was considered a distinctive American principle. Many a time have I heard the visitor who came to the public school which I attended, or the principal who occasionally himself addressed us, point out how glorious was the country where labor was respected, where the workingman was honored, where anyone who was honest and industrious could save money and improve his condition, and that of his family by honest hard work. But during the last generation all this is changed. Nobody hears such language anywhere. The whole tendency of legislation is to shorten the hours of work. The United States government has been directly prohibited by statute from permitting any person, however desirous he may be, to work on any government employment more than eight hours a day. ${ }^{2}$ The same rule is being applied in some

${ }^{1}$ Year-Book, Department of Agriculture, 1911, p. 638.

${ }^{2}$ Act of June 19, 1912, Pamphlet Laws, p. 137. "No laborer or mechanic shall be required or permitted to work more than eight hours in any one calendar day, upon such work." 
of the states to all employers. And when religious people get together in convention they often give ear to this seductive siren. You will observe that all this is quite different from the teaching of St. Paul. His is altogether old fashioned and out of date. He was a strenuous man and his conception of the good Christian was that he also should be strenuous. He admonishes his converts "not to be slothful in business, but to be fervent in spirit." When he describes in pictorial language the active and successful Christian, the image he takes is that of a soldier or an athlete. In his epistles there is no talk of eight hours a day but of accomplishing the end you have in view. But on the other hand when some religious people got together in a convention at Chicago a couple years ago, which they called a "Federal Council" they made one of their planks-"the gradual and reasonable reduction of hours of labor to the lowest practicable point and for that degree of leisure for all that is the condition of the highest human life." I had always supposed until I heard this deliverance that leisure was not the condition of the highest human life. That if it were, the people of the South Sea Island whose climate dispenses with the necessity of much clothing and who find food growing wild quite sufficient for their needs, would have obtained the highest eminence of humanity. This, however, is not true in point of fact. We all of us know that the highest human life has seldom been attained among the wealthy and leisure classes. Almost all of our great men worked their way up from the ranks and struggled strenuously in boyhood and in manhood with no thought of reducing their hours of labor to the lowest practicable point. Now it may be that these new lights are right; that all our old American ideas were fallacious and that Abraham Lincoln, Grover Cleveland and Robert Collyer, if I may refer to a distinguished clergyman who began his life as a boy in a blacksmith's shop, would have attained much greater eminence if they had been brought up in ease.

There is another tendency in some quarters which is not embodied in legislation but which has already attained considerable force. That is the syndicalist movement. This is distinctly a destructive movement. It is an avowedly destructive movement. Syndicalists aim to curtail the output of coal, to put boilers out of order, to shortcircuit dynamos, to destroy cables. They do not even pretend to observe the rules of civilized warfare. All this I take from an article 
by one of them, Andre Tridon, which was published in the Independent on the ninth of January. This article was approved by three others of their leaders W. D. Hayward, Frank Bohn and Joseph Ettor. Any one who has studied the writings or actions of the leaders of this movement in France, Germany, in England and in America is well aware that this statement expresses the sentiments and action of the organization perfectly.

Here then we have in our modern civilization a large and powerful organization whose aim is to destroy. The direct effect of the destruction is to increase the cost of living. It is this simple proposition that is constantly being ignored. We do not live on money. That is simply an instrument of exchange. We live on the product of human industry. The more of this product is destroyed, the less there is left. The direct effect of destruction is to increase the price of whatever remains. A curious instance of this, as I happened to learn in the course of my profession as a lawyer, is to be found in the Franco-Prussian war. The effect of the fighting in France was to break at least half the window glass and a great deal of the china and crockery in a large part of that country, which was overrun by hostile troops. The result of this was that after that war the factories of glass and crockery were taxed to their utmost capacity and they were unable to fulfill many of the contracts of delivery which they had made in this country, and the price of window glass and crockery went up, not only in France but in the United States.

There is no way to diminish the cost of living except to diminish the cost of production and whenever legislation is proposed which tends directly to increase the cost of production, we should ask ourselves, "Is the injury which is certain to come from this legislation more than compensated by the benefits which will accrue?" If it is we will accept the injury in consideration of the benefits. But in any case let us not act like spoiled children and cry because we cannot have any more of the cake that we already have eaten. 